\title{
Characterization of pre-gelatinized rice and bean flour
}

\author{
Ana Vânia CARVALHO ${ }^{1 *}$, Priscila Zaczuk BASSINELLO², Alessandro de Oliveira RIOS³, \\ Tayse Ferreira FERREIRA ${ }^{4}$, Rosângela Nunes CARVALHO², Selma Nakamoto KOAKUZU²
}

\begin{abstract}
The objective of this study was to develop a pre-gelatinized flour using a mixture of broken rice and split beans by thermoplastic extrusion, and to evaluate the physicochemical, nutritional, and technological quality of the final product. The extrusion parameters were maintained using three heating zones with temperatures of $30^{\circ} \mathrm{C}, 40{ }^{\circ} \mathrm{C}$, and $70{ }^{\circ} \mathrm{C}$; screw speed of $177 \mathrm{rpm}$; feed rate of $257 \mathrm{~g} / \mathrm{m}$, and circular matrix of $3.85 \mathrm{~mm}$. The following characterization analyses were performed: physicochemical, nutritional, water absorption index (WAI), water solubility index (WSI), and paste viscosity. The pre-gelatinized rice and bean flour had an intermediate value of WAI, $7.51 \mathrm{~g} / \mathrm{g}$, and high WSI value, $24.61 \%$. Regarding proteins, it was verified an average content of $12.9 \%$ in the final product. The amino acid contents found in the pre-gelatinized flour indicate that the mixture has the essential amino acids. It was also found that the pre-gelatinized flour supplies more than $60 \%$ of the essential amino acids recommended for children aged one to three years old. The gelatinized flour composed of broken rice and split beans is an alternative to the use of these by-products of the manufacture process of rice and beans to obtain a product with viable technological characteristics and high nutritional value.
\end{abstract}

Keywords: Phaseolus vulgaris; Oryza sativa; thermoplastic extrusion.

\section{Introduction}

Rice (Oryza sativa L.) and common beans (Phaseolus vulgaris L.) is a staple food of large part of the world's population, especially in Brazil, where they are the basis of daily meals and the major source of proteins to low-income populations (SICHIERI; CASTRO; MOURA, 2003). Some studies have reported that rice and beans provide high biological quality and high protein digestibility (around $80 \%$ ), and when ingested together they supply essential amino acids thus being characterized as complementary food (SICHIERI, 2002; TEBA; ASCHERI; CARVALHO, 2009).

Split beans is a by-product of the bean industrial processing, produced due to the rupture of the tegument covering the cotyledons. Similarly, around one third of the rice grains are broken during industrial processing, generating a byproduct commercially classified as "broken grain". Both of these by-products have low commercial value although they have nutritional properties similar to the original (KADAN; BRYANT; MILLER, 2008; SILVA; ASCHERI, 2009).

An alternative to aggregate value to these by-products would be their conversion into food ingredients to manufacture commercial or industrial products with high commercial aggregated value. Mixtures of vegetables, cereals, and legumes are a good option not only as commercially valued product, but also as nutritious formulations. Accordingly, Nicoletti et al. (2007) used whole soybean meal and broken rice to elaborate nutritiously enhanced pasta to obtain a product with high rate of acceptability and nutritional value higher to that obtained when it is processed with wheat flour only.

The consumption of precooked or instant food preparations has been gradually increasing all over the world and in Brazil as well. Some reasons for this increased demand and subsequent increased industrial production are the relatively low cost of the raw materials and the ease of preparation at home (OLIVEIRA et al., 2004). Therefore, the extrusion process has been recognized by the food industry as a very useful process enabling the manufacture of a wide array of food products when compared to other traditional processing systems. It is used to obtain modified or pre-gelatinized starches, widely used to obtain instant flours; ready to eat soups; semi-processed sauces, and ready to bake mixtures among others. Furthermore, it offers important differential advantages such as versatility, low cost, and efficiency besides contributing to environmental protection for being considered as a clean technology practice (CARVALHO, 2000; ASCHERI et al., 2006).

According to Guy (2001), extrusion is one of the most useful processes in the production of pre-gelatinized flour because it has a highly accurate control of the degree of gelatinization, in which small changes in the equipment and/or in the raw material may lead to different results in the final product quality.

The objective of this study was to develop pre-gelatinized flour with a mixture of broken rice and split beans flours and to evaluate the physicochemical, nutritional, and technological quality of the final product.

${ }^{1}$ Food Processing Laboratory, Embrapa Eastern Amazon Research Center, Trav. Dr. Enéas Pinheiro, s/n, CEP 66095-100, Belém, PA, Brazil, e-mail: anavania@cpatu.embrapa.br

${ }^{2}$ Food Technology Laboratory, Embrapa Rice and Beans Research Center, Rod. GO-462, Km 12, Rural Area, CP 179, CEP 75375-000, Santo Antônio de Goiás, GO, Brazil

${ }^{3}$ Department of Food Science, Food Science and Technology Institute, Federal University of Rio Grande do Sul - UFRGS, Porto Alegre, RS, Brazil

${ }^{4}$ Federal University of Pará - UFPA, Rua Augusto Corrêa, 01, CEP 66075-110, Belém, PA, Brazil

${ }^{*}$ Corresponding author 


\section{Materials and methods}

\subsection{Flour obtainment}

The raw materials used in the mixture preparation, broken rice and split beans (carioca type), obtained from the industrial processing of traditional commercial cultivars, were acquired from a local market in Goiania (Cristal Alimentos and Ibiá Alimentos Ltda, respectively). Both ingredients were grounded using a Willey knife mill until particles reached between 9 and 20 mesh. Thereafter, they were placed in plastic bags, separately, and stored at room temperature until flour preparation.

\subsection{Flour processing}

The formulation was performed by mixing $30 \%$ of split beans flour with $70 \%$ of broken rice flour, and the moisture content was adjusted to $21 \%$. The mixture was processed using a single screw extruder (Labor PQ30 - INBRAMAQ, Indústria de Máquinas Ltda, Ribeirão Preto, São Paulo - Brazil) with interchangeable screws; heating zones with temperature control, and screw speed set by a frequency adjustor. The following parameters were determined: temperature of the extruder zone (Zone $1=30{ }^{\circ} \mathrm{C}$; Zone $2=40^{\circ} \mathrm{C}$; Zone $3=70{ }^{\circ} \mathrm{C}$ ); screw speed of $177 \mathrm{rpm}$; feed rate of $257 \mathrm{~g} / \mathrm{min}$, and circular matrix of $3.85 \mathrm{~mm}$. The processed formula was collected manually, dried in force air oven at $60^{\circ} \mathrm{C}$ for three hours, and stored in plastic for further analysis.

\subsection{Physicochemical characterization of the raw material and flours}

The broken rice, split beans, and pre-gelatinized extruded flours were characterized for moisture; ashes; proteins; lipid content (ASSOCIATION..., 1997); total dietary fiber (calculated according to the gravimetric-enzymatic method $\mathrm{n}^{\circ} 991.43$ from ASSOCIATION..., 1997); carbohydrate, calculated by difference between 100 and the sum of the percentage of water, proteins, lipid and ashes; total energetic value (UNITED..., 1963); tannins (quantification by the colorimetric method of Follin-Denis no 952.3, ASSOCIATION..., 1997); phytates (HAUG; LANTZSCH, 1983); total amino acids (WHITE; HART; KRY, 1986); thiamine (vitamin B1); and riboflavin (vitamin B2) (according to standard methods EN14122:2003 and EN14152:2003 (EUROPEAN..., 2003a, b), respectively. Vitamin extraction was performed by acid hydrolysis and enzymatic treatment; thiamine was quantified by HPLC with pre-column derivatization by thiochrome, according to Presoto and Almeida-Muradian (2008); and the riboflavin content was determined by absorption using a fluorescence detector.

\subsection{Technological characterization of the pre gelatinized flour}

The determinations of water absorption index (WAI) and water solubility index (WSI) were performed following the methodology described by Anderson et al. (1969).

Paste viscosity characteristics of the pre-gelatinized flour was determined using a Rapid Visco Analyzer (RVA), Newport Scientific, Austrália, following the "Extrusion 1 noalcohol" protocol, which uses a grounded suspension (3 g in $25 \mathrm{~mL}$ ) adjusted to $14 \%$ moisture, and analyzed according to the following time/temperature scheme: $25^{\circ} \mathrm{C}$ for 2 minutes, heating from $25^{\circ} \mathrm{C}$ to $95^{\circ} \mathrm{C}$ at a rate of $14^{\circ} \mathrm{C} / \mathrm{min}$ keeping the paste at $95^{\circ} \mathrm{C}$ for 3 minutes, followed by cooling from $95^{\circ} \mathrm{C}$ to $25^{\circ} \mathrm{C}$ at a rate of $14^{\circ} \mathrm{C} / \mathrm{min}$, totaling a 20 minutes analysis. For the raw materials, the "Rice Rapid" protocol (AMERICAN..., 2000) was applied to RVA changing only the time/temperature conditions as follows: $50{ }^{\circ} \mathrm{C}$ for 1 minute, heating from $50{ }^{\circ} \mathrm{C}$ to $95^{\circ} \mathrm{C}$ at a rate of $9.375^{\circ} \mathrm{C} / \mathrm{min}$ keeping the paste at $95^{\circ} \mathrm{C}$ for 2.5 minutes, followed by cooling from $95^{\circ} \mathrm{C}$ to $25^{\circ} \mathrm{C}$ at a rate of $11.84^{\circ} \mathrm{C} / \mathrm{min}$.

\subsection{Statistical analysis}

All statistical analyses were carried out using the software STATISTICA (STATSOFT, 1995). The data was subjected to analysis of variance (ANOVA) and the Tukey's test.

\section{Results and discussion}

\subsection{Physicochemical characteristics of the raw materials and extruded pre-gelatinized flour}

Table 1 shows the physicochemical characterization of the broken rice, split beans, and the extruded pre-gelatinized flour.

Table 1. Physicochemical characterization of broken rice, split beans, and pre-gelatinized flour.*

\begin{tabular}{|c|c|c|c|}
\hline Determination & Broken rice & Split beans & Pre-gelatinized flour \\
\hline Moisture content (\%) & $11.74 \pm 0.74 \mathrm{a}$ & $10.84 \pm 0.05 a$ & $4.84 \pm 0.13 b$ \\
\hline Proteins (\%) & $7.50 \pm 0.20 c$ & $20.20 \pm 0.39 a$ & $12.88 \pm 0.22 b$ \\
\hline Lipids (\%) & $0.36 \pm 0.01 b$ & $0.88 \pm 0.03 \mathrm{a}$ & $0.08 \pm 0.01 c$ \\
\hline Ashes (\%) & $0.24 \pm 0.01 c$ & $3.79 \pm 0.12 \mathrm{a}$ & $1.56 \pm 0.06 b$ \\
\hline Total dietary fiber (\%) & $1.06 \pm 0.22 \mathrm{c}$ & $17.02 \pm 0.92 \mathrm{a}$ & $5.40 \pm 0.02 b$ \\
\hline Total carbohydrates (\%) & $80.16 \pm 0.92 \mathrm{a}$ & $64.29 \pm 0.36 b$ & $80.64 \pm 0.29 a$ \\
\hline Energetic value (kcal/100 g) & $353.81 \pm 3.01 \mathrm{a}$ & $345.68 \pm 0.65 b$ & $353.20 \pm 0.54 a$ \\
\hline Thiamine (mg/100 g) & $0.03 \pm 0.00 c$ & $0.45 \pm 0.00 \mathrm{a}$ & $0.14 \pm 0.00 \mathrm{~b}$ \\
\hline Riboflavin (mg/100 g) & $0.03 \pm 0.00 c$ & $0.15 \pm 0.00 \mathrm{a}$ & $0.06 \pm 0.00 \mathrm{~b}$ \\
\hline Tannins (mg/100 g) & $18.40 \pm 0.63 c$ & $461.37 \pm 10.86 a$ & $75.88 \pm 3.89 b$ \\
\hline Phytates (mg/100 g) & $34.00 \pm 1.03 \mathrm{c}$ & $399.25 \pm 13.26 \mathrm{a}$ & $127.00 \pm 14.50 \mathrm{~b}$ \\
\hline
\end{tabular}

${ }^{*}$ Wet basis results $(n=3)$. Values are means \pm standard deviations. a,b,cThe same letters in lines indicate no significant difference between the values by the Tukey test ( $\left.\mathrm{p}<0.05\right)$. 
Hagenimana, Ding and Fang (2006) found $12.4 \%$ of moisture, $0.41 \%$ of ashes, $6.71 \%$ of proteins, and $0.41 \%$ of lipid contents in broken rice flour; values close to those obtained in the present study. Regarding fiber content, the values found for broken rice and split beans flours are consistent with those specified in the "Tabela Brasileira de Composição de Alimentos" (UNIVERSIDADE..., 2006), which states contents of $1.1 \%$ and $18 \%$ for rice and bean flours, respectively.

Based on the results of material characterization (Table 1), it was observed that the split bean flour had significantly $(\mathrm{p}<0.05)$ higher protein content, almost three times more proteins than that of the broken rice flour as expected suggesting that formulations using bean flour would have their protein contents increased, as observed for the pre-gelatinized mixed flour, which has intermediate values of protein when compared with its original components individually. Another component worth mentioning is the split bean dietary fiber, which also showed significantly $(\mathrm{p}<0.05)$ high value, with an average content of $17.2 \%$, which could contribute to an increase in the levels of fiber in foods using that material as a complement, as in the case of pre-gelatinized flour, which showed intermediate fiber content significantly $(\mathrm{p}<0.05)$ different from that of raw flours, as also expected.

The pre-gelatinized flour had a protein content of $12.88 \%$. According to Resolution RDC 269, of September 22, 2005, referring to "Technical Recommendations of Daily Ingestion of Proteins, Vitamins and Minerals (IDR)", the estimated daily amount of proteins recommended for children from four to six years old is $19 \mathrm{~g} /$ day and $50 \mathrm{~g} /$ day for adults. That means that each $100 \mathrm{~g}$ of pre-gelatinized flour can supply $26 \%$ of adults' daily protein needs and $68 \%$ of children's. Thus, this flour has an excellent potential as a protein component to be used in puddings, instant lacteous mixes, and breakfast foods for example, in which thickening or water retention is desired, without the use of heating.

Legumes have more fiber content than cereals and are a good source of metabolized dietary fiber, as also found in the present study (Table 1), in which the content of total split beans fiber was almost 17 times higher (17.02\%) than that found for the broken rice flour (1.06\%), and the average values were significantly different $(\mathrm{p}<0.05)$. This characteristic enabled the development of a pre-gelatinized mixed flour with a fiber content of $5.40 \%$. According to the Ordinance $n^{\circ} .27$ of January 13, 1988, of the Brazilian Ministry of Heath; a solid food can be considered a source of dietary fiber when it has $3 \mathrm{~g} / 100 \mathrm{~g}$ of fiber (whole basis). Therefore, according to that resolution, it can be said that the rice and bean pre-gelatinized flour is a food source of dietary fiber.

It was also found that the pre-gelatinized flour lipid content of $0.08 \%$ was significantly ( $\mathrm{p}<0.05$ ) lower than the average value found for raw flour of rice and beans (Table 1). According to Camire, Camire and Krumhar (2000), this reduction could be attributed to the lipid-amylose complex formation, which is characterized by the addition of a non-polar portion of the lipid inside the amylose helix since the lipid extraction method using a solvent would be unable to disrupt that complex.
Vitamins B1 (thiamine) and B2 (riboflavin) are present in low amounts in foods in general although essential to humans, especially during pregnancy, lactation, and growth periods. The deficiency of these vitamins can cause serious illnesses such as beriberi and nervous system disorders, among others. Considering the intake of $0.6 \mathrm{mg} /$ day of B1 and B2 (IDR) for children from 4 to 6 years of age (BRASIL, 2005), each 100 grams of pre- gelatinized flour could supply around $23 \%$ and $10 \%$ of IDR of thiamine and riboflavin, respectively.

Although thiamine is more thermo labile than riboflavin, the extrusion process seems to produce low interference effects on the vitamin content of the final product. Observing the values in Table 1 and considering that $70 \%$ of broken rice and $30 \%$ of split beans were used in the extrusion, the amounts found $(0.14 \mathrm{mg} / 100 \mathrm{~g}$ of B1 and $0.06 \mathrm{mg} / 100 \mathrm{~g}$ of B2) in the pre- gelatinized flour were very close to the predicted values $(0.16 \mathrm{~g} / 100 \mathrm{~g}$ of B1 and $0.07 \mathrm{~g} / 100 \mathrm{~g}$ of B2). The stability observed during the processing of the flour was a result of appropriate temperature, moisture content, and $\mathrm{pH}$; relevant factors that should be taken into account by the food industry since this kind of flour is used in enriched formulations.

Anti-nutritional substances are those that affect the digestibility or the absorption of certain nutrients by the human body. Among them are phytates, polyphenols, and tannins, which occur widely in cereals and legumes. According to Martín-Cabrejas et al. (1999), the nutritive value of beans is limited by the presence of these anti-nutrients since beans need thermal processing before consumption.

Statistical difference was observed between the tannin contents found in split beans $(461.37 \mathrm{mg} / 100 \mathrm{~g})$ and broken rice flours ( $18.40 \mathrm{mg} / 100 \mathrm{~g})$. Phytates (Table 1) were present in the following amounts: $399.25 \mathrm{mg} / 100 \mathrm{~g}$ in the split beans flour and $34.00 \mathrm{mg} / 100 \mathrm{~g}$ in the broken rice flour, the means were significantly different $(\mathrm{p}<0.05)$. The pre-gelatinized extruded mixture had $75.88 \mathrm{mg} / 100 \mathrm{~g}$ of tannin and $127 \mathrm{mg} / 100 \mathrm{~g}$ of phytates; indicating the efficiency of the extrusion process in reducing this anti-nutritional factor content.

According to Shimelis and Rakshit (2007), pre cooking by extrusion is effective at removing or eliminating anti-nutritional factors; as also reported by Alonso, Aguirre and Marzo (1999) and Martín-Cabrejas et al. (1999), who verified that the extrusion process led to satisfactory reductions in phytate and tannin contents when they were assessing the effects of different processing methods on anti-nutritional compounds of beans.

\subsection{Raw material and pre-gelatinized extruded flour amino acid profile}

In general, statistical differences were found between the levels of amino acids between the three materials studied, and the pre-gelatinized flour tended to show intermediate levels when compared to those of raw rice and bean flours. In addition, the amino acid profile of the pre-gelatinized flour (Table 2) shows that a reasonable complementation of essential amino acids was obtained by mixing legumes and cereals, as desired. 
Table 2. Total protein (\%) and total amino acid contents of broken rice, split beans, and pre- gelatinized rice and bean flour and of the reference standard (INSTITUTE..., 2002), and chemical score for the pre gelatinized flour $\left(\mathrm{CS}_{\text {flour }}\right)$. $^{*}$

\begin{tabular}{|c|c|c|c|c|c|}
\hline \multirow{2}{*}{ 'Amino acids } & \multicolumn{5}{|c|}{ Amino acid content (mg/100 g) } \\
\hline & Broken rice & Split beans & Pre-gelatinized flour & IMA $^{\mathrm{a}}$ & $\mathrm{CS}_{\text {flour }}$ \\
\hline \multicolumn{6}{|l|}{ Essential } \\
\hline Threonine & $2.87 \pm 0.11 \mathrm{c}$ & $3.90 \pm 0.04 \mathrm{a}$ & $3.18 \pm 0.01 b$ & 2.7 & 1.18 \\
\hline Methionine & $2.27 \pm 0.01 \mathrm{a}$ & $0.84 \pm 0.03 c$ & $1.40 \pm 0.15 b$ & $2.5^{\mathrm{b}}$ & $0.74^{\mathrm{b}}$ \\
\hline$* 1 / 2$ Cystine & $0.60 \pm 0.12 \mathrm{a}$ & $0.22 \pm 0.01 \mathrm{c}$ & $0.44 \pm 0.07 b$ & & \\
\hline Tyrosine & $4.18 \pm 0.24 \mathrm{a}$ & $3.37 \pm 0.04 c$ & $3.47 \pm 0.01 b$ & & \\
\hline Phenylalanine & $4.78 \pm 0.02 b$ & $5.59 \pm 0.04 a$ & $4.80 \pm 0.01 b$ & $4.7^{\mathrm{c}}$ & $5.54^{\mathrm{c}}$ \\
\hline Lysine & $2.75 \pm 0.12 c$ & $7.27 \pm 0.09 \mathrm{a}$ & $4.73 \pm 0.07 b$ & 5.1 & 0.97 \\
\hline Histidine & $2.03 \pm 0.12 c$ & $2.97 \pm 0.01 \mathrm{a}$ & $2.36 \pm 0.02 b$ & 1.8 & 1.31 \\
\hline Tryptophan & $0.24 \pm 0.09 c$ & $0.44 \pm 0.04 b$ & $0.59 \pm 0.00 \mathrm{a}$ & 0.8 & 0.74 \\
\hline Glutamic acid & $16.97 \pm 0.48 \mathrm{a}$ & $14.50 \pm 0.02 \mathrm{c}$ & $14.77 \pm 0.07 b$ & & \\
\hline Proline & $4.30 \pm 0.12 \mathrm{a}$ & $3.68 \pm 0.01 b$ & $3.69 \pm 0.01 b$ & & \\
\hline Glycine & $4.18 \pm 0.12 \mathrm{a}$ & $3.86 \pm 0.02 b$ & $3.77 \pm 0.07 b$ & & \\
\hline Alanine & $5.38 \pm 0.12 \mathrm{a}$ & $4.17 \pm 0.04 c$ & $4.58 \pm 0.03 b$ & & \\
\hline Total protein & $8.37 \pm 0.22 c$ & $22.55 \pm 0.43 a$ & $13.54 \pm 0.23 b$ & & \\
\hline
\end{tabular}

It was verified that (Table 2) the broken rice flour had lysine and tryptophan as limiting amino acids, while the split bean flour showed limiting sulphur amino acids (methionine and cysteine) and tryptophan, consistent with the results found by Silva, Ascheri and Pereira (2008), who found lysine as limiting in rice flour, and Pires et al. (2006), who reported a deficiency in cystein and methionine in bean flour.

Pires et al. (2006) reported that a protein that presents a chemical score higher than 1.0 for all amino acids is considered of high nutritional value, while amino acids with chemical score lower than 1.0 are considered limiting. Thereby, the pre-gelatinized flour had lysine, methionine, cysteine, and tryptophan as limiting amino acids. It was also found that the pre- gelatinized flour was able to supply more than $60 \%$ of the essential amino acids recommended by IMA (INSTITUTE..., 2002) for children aged from one to three years old.

\subsection{Technological characterization of the pre-gelatinized extruded flour}

The mixed pre-gelatinized flour had a WAI of $7.51 \mathrm{~g} / \mathrm{g}$ and WSI of 24.61\%. Clerice and El-Dash (2008) and Silva and Ascheri (2009) found WSI of $15.92 \%$ and $7.24 \%$, values significantly lower than those observed in this study, which could be attributed to different processing conditions or to the addition of bean flour.
Filli et al. (2010), studying the influence of extrusion parameters in soybean and corn flour, reported that legumes can provide increases in WAI since raw material have considerable amounts of proteins, winch are water soluble molecules that contribute to increase the content of components in suspension; however, Martín-Cabrejas et al. (1999) suggested that the denaturation of proteins during the extrusion process may lead to the loss of solubility. Therefore, the high solubility index obtained in this study (24.61\%) suggests low protein denaturation due to the mild conditions of the extrusion process and high moisture.

Paste viscosity is an important parameter to be evaluated when studying the functional properties of starchy foods; it is a way to assess the degree of degradation that occurs in these materials during thermal treatments (CARVALHO et al., 2010). Figure 1 shows the viscosity curve of the pre-gelatinized rice and bean flour

It was observed that the pre-gelatinized flour had initial viscosity value higher than those shown by the broken rice and split bean flours. According to Nascimento et al. (2007), raw flours have initial low viscosity values because raw starches are insoluble in cold water, while thermally treated starches show an initial viscosity value due to irreversible tumescence of starch granules, reflecting their degree of pre-gelatinization.

It is was also observed that the broken rice grain flour showed high values of peak and final viscosities; contrary to 


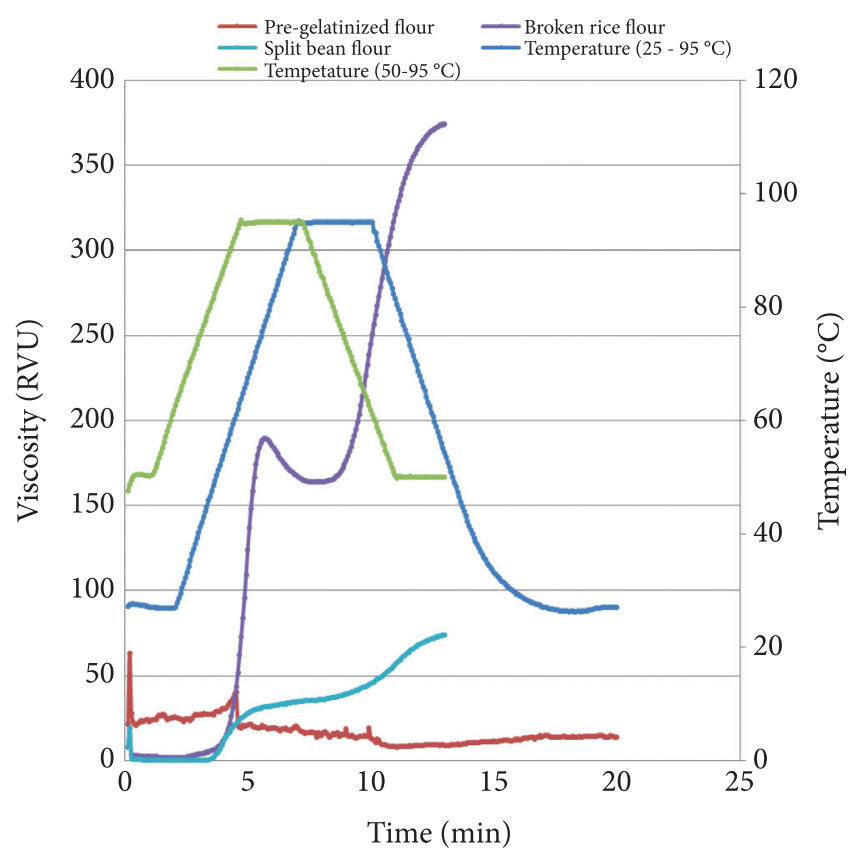

Figure 1. Viscosity profile of the pre-gelatinized rice and bean flour by RVA.

those of split beans and pre-gelatinized rice and bean flour. According to Silva and Ascheri (2009), the high values for maximum and final viscosities found in the broken rice flour may be attributed to the high amount of intact starch granules since they were not subjected to any kind of treatment implying any modification in the starchy structure, and, consequently in its technological characteristics. However, the low values found in the split bean flour could be attributed to the presence of low starch content and the presence of lipids, proteins, and dietary fiber, while in the pre-gelatinized flour the low values of peak and maximum viscosity found probably occurred due to the extrusion process, which caused changes in the starch granular structure.

Summarizing, the pre-gelatinized flour developed showed relatively high initial viscosity and low final viscosity when compared with those of raw flours; therefore the pre- gelatinized flour has adequate characteristics for use as instant flour, in agreement with the findings of with Carvalho et al. (2010), who stated that products with high initial viscosity can be used in instant product elaboration due to their high degree of water solubility. However, it is recommended to perform preliminary tests to evaluate the potential use of the pre-gelatinized flour obtained as an ingredient in the development of novel foods.

\section{Conclusion}

The broken rice and split bean pre-gelatinized flour is an interesting alternative for the use of the by-products obtained from the industrial process of rice and beans resulting in products with high nutritional value, especially due to their dietary fiber content and the presence of ideal amounts of the majority of the essential amino acids to human diet. With regards to technological characteristics, the pre-gelatinized flour showed an intermediate value of water absorption index and high water solubility index.

\section{References}

ALONSO, R.; AGUIRRE, A.; MARZO, F. Effects of extrusion and traditional processing methods on antinutrients and in vitro digestibility of protein and starch in faba and kidney beans. Food Chemistry, v. 68, p. 159-165, 1999. http://dx.doi.org/10.1016/ S0308-8146(99)00169-7

AMERICAN ASSOCIATION FOR CLINICAL CHEMISTRY - AACC. AACC International Approved Methods. Method 61-02 Determination of Pasting Properties of Rice with the Rapid Visco Analyser. 10th ed. AACC, 2000. v. 2, p. 1-4.

ANDERSON, R. A. et al. Gelatinization of corn grits by roll and extrusuion cooking. Cereal Science Today, v. 14, n. 1, p. 4-11, 1969.

ASCHERI, D. P. R. et al. Efeito da extrusão sobre a adsorção de água de farinhas mistas pré-gelatinizadas de arroz e bagaço de jabuticaba. Ciência e Tecnologia de Alimentos, v. 26, n. 2, p. 325-335, 2006. http://dx.doi.org/10.1590/S0101-20612006000200015

ASSOCIATION OF OFFICIAL ANALYTICAL CHEMISTS - AOAC. Official methods of analysis of the Association of Official Analytical Chemists. 16th ed. Washington: AOAC; 1997.

BRASIL. Resolução RDC no 269 de 22 setembro de 2005. Agência Nacional de Vigilância Sanitária adota o "Regulamento Técnico sobre a Ingestão Diária Recomendada (IDR) de Proteínas, Vitaminas e Minerais" e dá outras providências. Diário Oficial da República Federativa do Brasil, Brasília, DF, 23 set. 2005. Secão 1, n. 184, p. 372.

CAMIRE, M. E.; CAMIRE, A.; KRUMHAR, K. Chemical and nutritional changes in foods during extrusion. Critical Reviews in Food Science and Nutrition, v. 29, n. 1, p. 35-57, 1990. http:// dx.doi.org/10.1080/10408399009527513

CARVALHO, R. V. Formulações de snacks de terceira geração por extrusão: caracterização texturométrica e microestrutural. 2000. $89 \mathrm{f}$. Dissertação (Mestrado em Ciência de Alimentos)-Universidade Federal de Lavras, Lavras, 2000.

CARVALHO, A. V. et al. Caracterização tecnológica de extrusados de terceira geração à base de farinhas de mandioca e pupunha. Ciência e Agrotecnologia, v. 34, n. 4, p. 995-1003, 2010. http:// dx.doi.org/10.1590/S1413-70542010000400028

CLERICE, M. T. P. S.; EL-DASH, A. A. Características tecnológicas de farinhas de arroz pré-gelatinizadas obtidas por extrusão termoplástica. Ciência e Agrotecnologia, v. 32, n. 5, p. 1543-1550, 2008. http:// dx.doi.org/10.1590/S1413-70542008000500028

EUROPEAN COMMITTEE FOR STANDARDIZATION. EN 14152: 2003-09: Lebensmittel - Bestimmung von Vitamin $\mathrm{B}_{1}$ mit HPLC. Foodstuffs: Determination of vitamin $\mathrm{B}_{1}$ by HPLC, English version of DIN EN 14122. Berlin: European Standard, Sept 2003a. 16 p.

EUROPEAN COMMITTEE FOR STANDARDIZATION. EN 14152: 2003-10: Lebensmittel - Bestimmung von Vitamin $\mathrm{B}_{2}$ mit HPLC. Foodstuffs: Determination of vitamin $\mathrm{B}_{2}$ by HPLC, English version of DIN EN 14152. Berlin: European Standard, Oct 2003b. 14 p.

FILLI, K. B. et al. Influence of extrusion variables on some functional properties of extruded millet-soybean for the manufacture of 'fura': A Nigerian traditional food. African Journal of Food Science, v. 4, n. 6, p. 342- 352, 2010.

GUY, R. Extrusión de los alimentos. Zaragoza: Acribia, 2001. 208 p. 
HAGENIMANA, A.; DING, X.; FANG, T. Evaluation of rice flour modified by extrusion cooking. Journal of Cereal Science, n. 43, p. 38-46, 2006. http://dx.doi.org/10.1016/j.jcs.2005.09.003

HAUG, W.; LANTZSCH, H. Sensitive Method for the Rapid Determination of Phytate in Cereals and Cereals Products. Journal of the Science of Food and Agriculture, v. 34, p. 1423-1426, 1983. http://dx.doi.org/10.1002/jsfa.2740341217

INSTITUTE OFMEDICINE OF THENATIONAL ACADEMIES - IMA. Protein and amino acids. In: INSTITUTE OF MEDICINE OF THE NATIONAL ACADEMIES. Dietary reference intakes for energy, carbohydrate, fiber, fat, fatty acids, cholesterol, protein, and amino acids. Washington: The National Academies Press, 2002. part 2, cap. 10, p. 72.

KADAN, R. S.; BRYANT, R. J.; MILLER, J. A. Effects of milling on functional properties of rice flour. Journal of Food Science, v. 73 , n. 4 , p. 151-154, 2008. http://dx.doi.org/10.1111/j.17503841.2008.00720.x

MARTÍN-CABREJAS, M. A. et al. Modifications to Physicochemical and Nutritional Properties of Hard-To-Cook Beans (Phaseolus vulgaris L.) by Extrusion Cooking. Journal of Agriculture and Food Chemistry, n. 47, p. 1174-1182, 1999. http://dx.doi.org/10.1021/ jf980850m

NASCIMENTO, K. O. et al. Propriedades de pasta de farinhas de trigo-soja pré-cozidas por extrusão. Alimentos e Nutrição, v. 18, n. 4, p. 387-395, 2007.

NICOLETTI, A. M. et al. Uso de subprodutos agroindustriais no desenvolvimento de macarrão nutricionalmente melhorado. Alimentos e Nutrição, v. 18, p. 421-429, 2007.

OLIVEIRA, M. F. et al. Qualidade de cozimento de massas de trigo e soja pré-cozidas por extrusão. Pesquisa Agropecuária Brasileira, v. 39, n. 5, p. 501-507, 2004. http://dx.doi.org/10.1590/S0100204X2004000500013

PIRES, C. V. et al. Qualidade nutricional e escore químico de aminoácidos de diferentes fontes protéicas. Ciência e Tecnologia de Alimentos, v. 26, n. 1, p. 179-187, 2006. http://dx.doi.org/10.1590/ S0101-20612006000100029

PRESOTO, A. E. F.; ALMEIDA-MURADIAN, L. B. Validação de Métodos Cromatográficos por CLAE para Análises das Vitaminas
$\mathrm{B}_{1}, \mathrm{~B}_{2}, \mathrm{~B}_{6}$ e Niacina Naturalmente presentes em Farinhas de Cereais. Química Nova, v. 31, n. 3, p. 498-502, 2008. http://dx.doi. org/10.1590/S0100-40422008000300006

SICHIERI, R. Dietary patterns and their associations with obesity in the Brazilian city of Rio de Janeiro. Obesity Research, v. 10, p. 42-49, 2002. http://dx.doi.org/10.1038/oby.2002.6

SICHIERI, R.; CASTRO, J. F. G.; MOURA, A. S. Fatores associados ao padrão de consumo alimentar da população brasileira urbana. Caderno de Saúde Pública, n. 19, p. S47-S53, 2003. Suplemento 1.

SILVA, R. F.; ASCHERI, J. L. R.; PEREIRA, R. G. F. A. Composição química de farinhas pré-cozidas por extrusão elaboradas com arroz e café torrado. Revista do Instituto Adolfo Lutz, v. 67, n. 1, p. 52-58, 2008.

SILVA, R. F.; ASCHERI, J. L. R. Extrusão de quirera de arroz para uso como ingrediente alimentar. Brazilian Journal of Food Technology, v. 12, n. 3, p. 190-199, 2009. http://dx.doi.org/10.4260/ bjft2009800900012

SHIMELIS, E. A.; RAKSHIT, S. K. Effect of processing on antinutrients and in vitro digestibility of kidney bean (Phaseolus vulgaris, L.) varieties grown in East Africa. Food Chemistry, v. 103, p. 161172, 2007. http://dx.doi.org/10.1016/j.foodchem.2006.08.005

STATSOFT. STATISTICA for Windows. versão 5.0. Tulsa: Statsot Inc., 1995.

TEBA, C. S.; ASCHERI, J. L. R.; CARVALHO, C. W. P. Efeito dos parâmetros de extrusão sobre as propriedades de pasta de massas alimentícias pré-cozidas de arroz e feijão. Alimentos e Nutrição, v. 20, n. 3, p. 411-426, 2009.

UNITED STATES DEPARTAMENT OF AGRICULTURE - USDA. Composition of foods. Washington: Agricultural Research Center Service, 1963. 190 p. (Agriculture handbook n. 8).

UNIVERSIDADE ESTADUAL DE CAMPINAS - UNICAMP. Tabela brasileira de composição de alimentos - TACO. versão 2. 2. ed. Campinas: UNICAMP/NEPA, 2006.113 p. Disponível em: <www.unicamp.br/nepa/taco/>. Acesso em: 20 out 2010.

WHITE, J. A.; HART, R. J.; KRY, J. C. An evaluation of the Waters Pico-Tag system for the amino acid analysis of food materials. Journal Automatic Chemistry, v. 8, p. 170-177, 1986. http://dx.doi. org/10.1155/S1463924686000330 